\title{
Het hart, de ruggengraat en de hersenpan: Perspectieven op gezondheidsgedrag
}

Citation for published version (APA):

de Vries, N. K. (2000). Het hart, de ruggengraat en de hersenpan: Perspectieven op gezondheidsgedrag. Universiteit Maastricht. https://doi.org/10.26481/spe.20001109nv

Document status and date:

Published: 09/11/2000

DOI:

10.26481/spe.20001109nv

Document Version:

Publisher's PDF, also known as Version of record

\section{Please check the document version of this publication:}

- A submitted manuscript is the version of the article upon submission and before peer-review. There can be important differences between the submitted version and the official published version of record.

People interested in the research are advised to contact the author for the final version of the publication, or visit the DOI to the publisher's website.

- The final author version and the galley proof are versions of the publication after peer review.

- The final published version features the final layout of the paper including the volume, issue and page numbers.

Link to publication

\footnotetext{
General rights rights.

- You may freely distribute the URL identifying the publication in the public portal. please follow below link for the End User Agreement:

www.umlib.nl/taverne-license

Take down policy

If you believe that this document breaches copyright please contact us at:

repository@maastrichtuniversity.nl

providing details and we will investigate your claim.
}

Copyright and moral rights for the publications made accessible in the public portal are retained by the authors and/or other copyright owners and it is a condition of accessing publications that users recognise and abide by the legal requirements associated with these

- Users may download and print one copy of any publication from the public portal for the purpose of private study or research.

- You may not further distribute the material or use it for any profit-making activity or commercial gain

If the publication is distributed under the terms of Article $25 \mathrm{fa}$ of the Dutch Copyright Act, indicated by the "Taverne" license above, 
Het hart, de ruggengraat en de hersenpan

Perspectieven op gezondheidsgedrag

\author{
Rede
}

uitgesproken bij de aanvaarding van het ambt van hoogleraar

gezondheidswoorlichting en -bevordering

aan de Faculteit der Gezondheidswetenschappen van de Universiteit

Maastricht op

donderdag 9 november 2000

door

N.K. de Vries 

Soms neemt een mens wel eens een radicale en ingrijpende beslissing. Bij deze gelegenheid, de aanvaarding van het ambt als hoogleraar Gezondheidsvoorlichting, realiseer ik me dat als geen ander: mijn wens om dit te doen heeft grote repercussies voor mijn gezin, mijn sociale omgeving (familie, vrienden en collega's), mijn vrijetijdsbesteding, mijn woonomstandigheden en ga zo maar door. Om op die woonomstandigheden door te gaan: op zoek naar een huis liepen wij tegen een carré-boerderij aan. Na bezichtiging en flink wat afweging en deliberatie besloten we niet verder op dit aanbod in te gaan. Voor deze beslissing hadden we heel rationele overwegingen, geografisch, fysiek en financieel. Carolien en ik hebben echt uiterst zorgvuldig alle voors en tegens op een rijtje gezet, en besloten niet door te zetten. Maar het huis liet ons niet los en kwam steeds bij ons beiden weer op. Het duurde twee weken voordat we tegen elkaar zeiden: dat huis in de Heek, wat jammer toch he. Uiteindelijk hebben we ons hart laten spreken en het huis na een nieuwe bezichtiging toch gekocht. Ik denk (en hoop) dat dit geen slechte beslissing is.

Met dit voorbeeld wil ik aangeven dat afwegingsprocessen zich op allerlei manieren voordoen. In mijn vak, de Gezondheidsvoorlichting, is het vrijwel gemeengoed om gezondheidsgedrag te verklaren op grond van de keuzes die mensen maken en de overwegingen die daar een rol bij spelen. Om de relevante overwegingen te bepalen worden mensen bevraagd over alle gevolgen van een bepaald gedrag die mogelijk van toepassing zouden kunnen zijn. Interventies, bedoeld om dat gedrag te beïnvloeden, worden dan afgestemd op de overwegingen die verschillend zijn voor mensen die zich gezond en mensen die zich ongezond gedragen: juist die overwegingen worden als determinanten van gedrag beschouwd. Het idee is dat mensen hun ideeen, cognities noemen wij dat, integreren en tegen elkaar afwegen. Het resultaat is een voorkeur, die zich uitdrukt in gedrag. Modellen die zich baseren op dit soort afwegingsprocessen worden met succes toegepast in de gezondheidsvoorlichting, maar er is meer.

Hopelijk heb ik u met mijn voorbeeld nu al overtuigd van mijn opvatting dat dit proces zich lang niet altijd, of zelfs meestal niet, op deze manier afspeelt. In deze inaugurele rede wil ik mijn licht laten schijnen over een paar alternatieven voor die complete 
afwegingsprocessen als determinant voor gezondheidsgedrag, die ik in de titel heb aangeduid met "de hersenpan". Soms doen mensen wat hun gevoel hen ingeeft, dat heb ik in de titel aangeduid met "het hart". Soms volgen zij een ingeving, soms gedragen ze zich zonder welke afweging dan ook, op grond van automatisme of gewoonte; dat noem ik in de titel "de ruggengraat". Ik zall proberen een aantal mogelijkheden te schetsen voor interventies die zich op die alternatieve verklaringen richten. Dat impliceert wel dat $u$ aan het eind van dit betoog waarschijnlijk meer een idee heeft van de richting die ik binnen het vak verder zou willen ontwikkelen dan van de exacte inhoud van die nieuwe ontwikkelingen. In die zin is het een soort van onderzoeksagenda waar ik in de komende jaren samen met collega's aan will werken.

Eerst zal ik nu kort wat dieper ingaan op de afwegingsmodellen, de hersenpan. Daarna zal ik aandacht besteden aan de manier waarop processen in het hart en de ruggengraat kunnen bijdragen aan een beter begrip van gezondheidsgedrag.

\section{Waardeverwachtingsmodellen}

In de gezondheidsvoorlichting analyseert men gewoonlijk de determinanten van gedrag aan de hand van de zogenaamde waardeverwachtingsmodellen, die ook wel sociaal-cognitieve modellen worden genoemd. Deze modellen voorspellen gedrag uit een aantal cognitieve factoren: al dan niet juiste subjectieve oordelen van mensen over het gedrag in kwestie. Het sociale aspect is dat deze ideeën veelal door anderen worden beïnvloed. Als voorbeeld, en met het gevaar een aantal mensen nu al te gaan vervelen, toon ik u de theorie van gepland gedrag van Ajzen (1991).

Zoals de illustratie laat zien kan gedrag volgens Ajzen worden voorspeld uit drie variabelen, respectievelijk de attitude, de subjectieve norm en de ervaren controle van de persoon. 


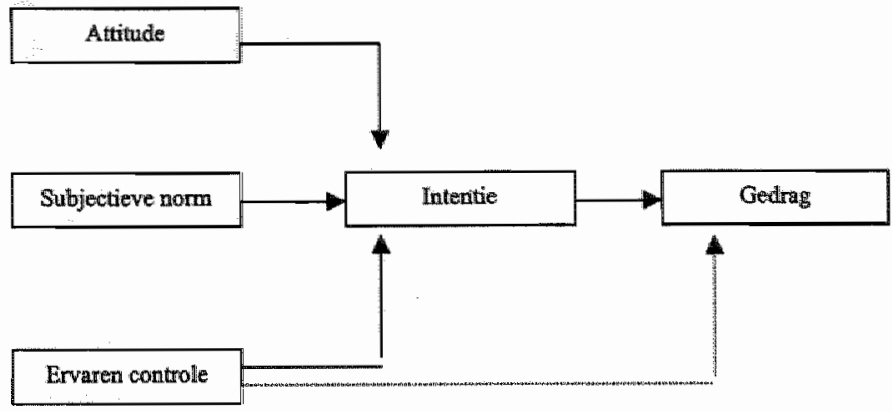

De attitude is een persoonlijke afweging van voor- en nadelen die de persoon verbonden ziet aan het gedrag; de subjectieve norm beschrijft de indruk die de persoon heeft van wat de mensen om haar of hem heen wenselijk achten en de ervaren controle, of ook wel eigen effectiviteit, is een neerslag van de indruk van de eigen mogelijkheden en onmogelijkheden om het gedrag in kwestie te vertonen. Samen combineren deze drie variabelen in een intentie, de bedoeling om het gedrag te vertonen (of niet), die zich kan omzetten in gedrag. Omdat het voor het omzetten van intentie in gedrag van belang is dat mensen dat ook daadwerkelijk kunnen is er ook een directe invloed van de ervaren controle (de inschatting van de eigen mogelijkheden) op gedrag. Een voorbeeld, terugredenerend: om minder vet te eten (gedrag) moet iemand van plan zijn om dat te doen (intentie) en mogelijkheden zien dat plan in actie om te zetten (eigen effectiviteit); de intentie is weer het gevolg van een positieve evaluatie van het gedrag (positieve attitude die er uit voortkomt dat men meer voordelen dan nadelen verbonden ziet aan het gedrag), een ondersteunende sociale omgeving (de partner helpt ook mee om op vet te letten) en voldoende mogelijkheden (een persoon die op reis is en daarom iedere dag in een restaurant moet eten ervaart geen controle en zet daarom de plannen om minder vet te eten maar even uit het hoofd).

Het model specificeert ook nog waaruit de drie basale determinanten, attitude, subjectieve norm en ervaren controle zijn opgebouwd en hoe ze derhalve kunnen worden gemeten. Ik behandel even alleen de attitude: volgens het model is die een combinatie van overwegingen en evaluaties. 
Owerwegingen
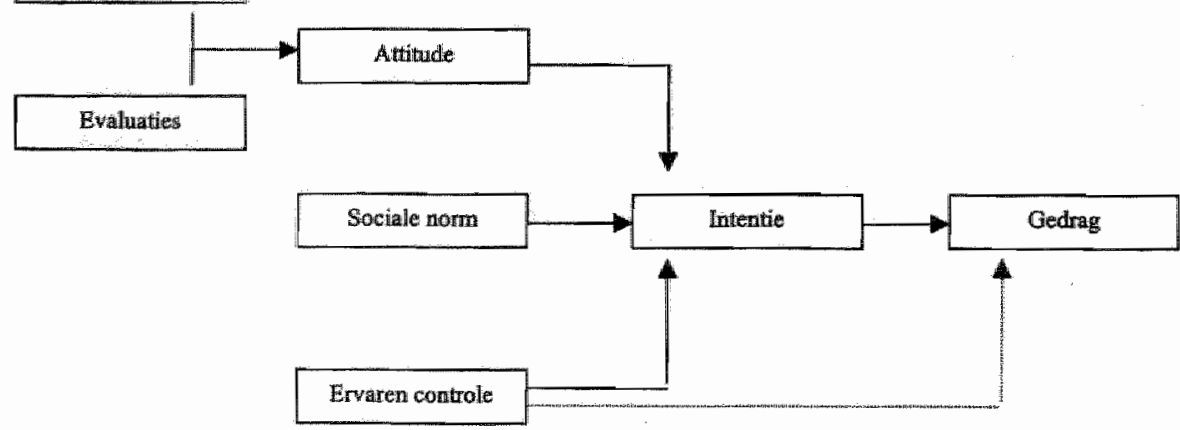

Een overweging is de ervaren waarschijnlijkheid dat het gedrag in kwestie een bepaald gevolg zal hebben (b.v. in de vorm: door minder vet te eten verlies ik lichaamsgewicht). Een evaluatie is de waardering voor dat gevolg (zoals: gewichtsverlies vind ik heel erg prettig). Zo zijn er tal van mogelijke gevolgen en die moeten volgens het model allemaal worden meegenomen in de afweging. Technisch: men kan deze overtuigingen en evaluaties meten, en dan combineren volgens een formule:

$$
\mathrm{A}=\sum_{\mathrm{i}=1}^{n} \mathrm{~b}_{i} \mathrm{e}_{i}
$$

waarin A staat voor Attitude, $\underline{b}$ voor belief (dat is de waarschijnlijkheid dat een gedrag een bepaald gevolg heeft) en e voor de evaluatie van dat gevolg. Zoals de formule weergeeft wordt de waarschijnlijkheid van een bepaald gevolg vermenigvuldigd met de evaluatie van het gevolg. Als men dat doet voor een hele serie mogelijke gevolgen en men telt die produkten op, dan kan de attitude worden voorspeld. Iemand zou de volgende overwegingen kunnen hebben: door minder vet te eten verlaag ik de kans op hart- en vaatziekten en dat vind ik heel erg positief; door minder vet te eten verlies ik gewicht en dat is in mijn geval positief; door minder vet te 
eten smaakt de maaltijd minder lekker en dat vind ik niet zo heel fijn; enzovoort. Twee grote voordelen en een betrekkelijk gering nadeel leiden tot een positieve attitude.

De formule beschrijft een lineair-compensatorische integratie: heel veel kleine voordelen kunnen immers opwegen tegen éen heel groot nadeel. In onderzoek ziet men niet zelden dat mensen worden bevraagd over een twintigtal mogelijke gevolgen, die dan dus allemaal zouden moeten meewegen in het eindoordeel.

Ik heb in het voorgaande alleen het model van Ajzen uitgewerkt, maar neemt $u$ van mij maar aan dat mutatis mutandis hetzelfde geldt voor andere belangrijke determinantenmodellen in de GVO, zoals het ASEmodel, het Health Belief Model en de Protection Motivation Theory.

In het volgende zal ik proberen een aantal kanttekeningen te maken bij deze zogenaamde waardeverwachtingsmodellen. $U$ zult mij niet horen beweren dat deze modellen niet nuttig of zelfs fout zouden zijn; zo gaat dat niet in de wetenschap. Het zou ook onterecht zijn, want deze modellen voorspellen gedrag soms goed, en er zijn succesvolle interventies ontwikkeld op grond van de analyses die ik u zojuist probeerde uit te leggen. De vakgroep GVO heeft daar een grote bijdarge aan gelleverd.

Wel denk ik dat de veronderstelde processen zich slechts in een beperkt aantal situaties voordoen. Juist bij hele alledaagse, vaak terugkerende gedragingen zijn er ook andere manieren waarop mensen tot een impliciete of expliciete keuze komen. Het meeste gedrag waarop de GVO zich richt bestaat uit dat soort alledaagse activiteiten: de speerpunten in het veld zijn bewegen, roken, alcoholconsumptie, veiligheid en voeding. Volgens mij heeft GVO er dan ook baat bij meer kennis te verzamelen over minder bewuste afwegingen en processen waarin zelfs geen enkele afweging wordt gemaakt. I $k$ begin met een aantal beperkingen en problemen met het model zelf om daarna over te gaan naar heel andere denkwerelden. De eerste kanttekening betreft het aantal overwegingen dat mensen zouden betrekken in een attitude-oordeel. 


\section{Saillantie}

Zelfs als mensen afwegingen maken zoals die worden beschreven in het model van Ajzen is het de vraag of dit model altijd goed weergeeft op welke manier dat in zijn werk gaat. Heel veel studies hebben in kaart gebracht welke gevolgen mensen zien van roken, AIDSpreventief gedrag, drinken, orgaandonatie, et cetera. Er wordt dan na een initiele inventarisatie meestal gewerkt met vragenlijsten die rond de twintig mogelijke consequenties aflopen (met uitschieters naar wel 50 gevolgen die worden beoordeeld op waarschijnlijkheid en evaluatie). Vanuit de cognitieve psychologie kunnen vraagtekens gezet worden bij de mogelijkheid voor de menselijke beslisser een dergelijke hoeveellheid informatie te integreren (zie bijwoorbeeld Taylor, 1998). Ook zijn er grote problemen met de integratieregel die in het model wordt gesuggereerd: de psychologische besliskunde laat zien dat compensatorische beslisregels (waarin bijvoorbeeld één groot nadeel kan worden gecompenseerd door vele kleine voordelen) eerder de uitzondering vormen dan de regel. Dergelijke regels zijn te ingewikkeld en kosten te veel moeite. Vaker gebruiken mensen zogenaamde non-compensatorische regels of heuristieken, vooral wanneer ze niet erg gemotiveerd zijn of ook nog andere dingen aan hun hoofd hebben (zie, b.v., Jaccard et al, 1995). Dat zou kunnen inhouden dat bepaalde keuzemogelijkheden afvallen omdat er één groot nadeel aan kleeft, of dat bepaald gedrag wordt vertoond omdat het één belangrijk voordeel heeft. Mensen roken omdat hun lichaam daar om vraagt, ondanks de vele nadelen die zij zien.

Op grond van deze twijfels is in mijn vorige werkkring een onderzoekslijn gestart rondom de saillantie van overwegingen waarin ik heb samengewerkt met Frenk van Harreveld en Joop van der Pligt (voor een overzicht zie Van der Pligt, de Vries, Manstead en van Harreveld, 2000). Er van uitgaande dat er, althans in een te begrenzen aantal gevallen, sprake zou kunnen zijn van een proces van integratie van informatie om tot een eindoordeel te komen, hebben wij op verschillende manieren respondenten laten bepalen welke van de aangeboden consequenties van gedrag zij echt belangrijk voor hun oordeel achten. De gemakkelijkste manier is een eenvoudige selectie- 
taak: uit een lijst van 15 mogelijke gevolgen van roken kruisen mensen aan welke consequenties voor hen echt belangrijk zijn. Sommigen kiezen dan één consequentie, velen geven twee belangrijke gevolgen aan, en maar heel weinig mensen achten meer dan vier consequenties doorslaggevend voor hun keuze. Wanneer nu scores worden berekend op grond van die geselecteerde consequenties kan men attitudes, intenties en gedrag minstens net zo goed en regelmatig ook beter voorspellen dan wanneer de totale lijst van attributen wordt gebruikt.

Belangrijker nog, de verschillen tussen rokers en niet-rokers op de attitudemaat worden veel duidelijker: de maat is dus sensitiever. Rokers verschillen heel sterk van niet-rokers op de individueel belangrijke overwegingen; bij de onbelangrijke overwegingen is het verschil nagenoeg afwezig.

Interessant is het ook om de selectie die rokers en niet-rokers maken met elkaar te vergelijken. Rokers selecteren relatief meer korte termijn voordelen als zijnde doorslaggevend voor hun mening. Dat zijn met name direkt bellonende factoren: roken helpt om te ontspannen en maakt de omgang met anderen gemakkelijker. Niet-rokers letten vooral op gezondheidsgevolgen en die liggen meestal op de lange termijn zoals de kans op hart- en vaatziekten en longkanker. Ook de nadelen voor anderen worden meer genoemd door niet-rokers dan door rokers.

De groepen verschillen bijvoorbeeld niet aangaande hun beoordeling van de waarschijnlijkheid dat roken leidt tot longkanker en tot hart- en vaatziekten, noch in de evaluatie van dit gevolg; voor veel rokers is het alleen minder belangrijk. Met andere woorden: als we meer recht doen aan de menselijke beperkingen aangaande informatieverwerking krijgen we ook een ander beeld van de oorzaken die zij aangeven voor gedrag.

Een volgend punt is dat ons inzicht in de psychologische toestand van de persoon verbetert. Van belang is met name de ambivalentie van personen. Ambivalentie is de toestand waarin een persoon zowel voorals nadelen van een bepaald gedrag ervaart; men is verscheurd tussen voors en tegens, tussen doen en niet doen. Dat heeft directe implicaties voor de veranderingsbereidheid van personen. Het is gemakkelijker iemand te overtuigen die niet helemaal meer zeker is 
van een keuze dan iemand die alleen maar voordelen van het betreffende gedrag ziet. Boodschappen kunnen daarop worden afgestemd. Wij hebben in het project van Van Harreveld aangetoond dat ambivalentie beter kan worden voorspeld en begrepen wanneer men zich richt op de individueel belangrijke overwegingen dan wanneer men alle mogelijke gevolgen daarin betrekt. Bijvoorbeeld: dat roken stinkt leidt nauwelijks tot ambivalentie bij rokers, want men vindt deze consequentie niet belangrijk. Voor een derde van de rokers speelt de kans op ziekten nauwelijks een rol al zijn ze wel overtuigd dat deze ziekten een ernstig gevolg zijn van het roken. Voorlichting zou zich dus kunnen richten op het benadrukken van gevolgen die mensen al belangrijk vinden of op het beinvloeden van het belang van bepaalde overwegingen. Met dit afstemmen op ideeen van de ontvanger, met een goed Engels woord aangeduid als 'tailloring', wordt op dit moment al veel ervaring opgedaan binnen de vakgroep

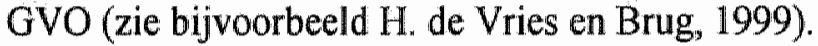

\section{Affect}

De waardeverwachtingsmodellen, en toegegeven, ook onze eigen toevoeging aangaande de saillantie van overwegingen, gaan eigenlijk uit van tamelijk koude redeneerprocessen, van processen in de 'hersenpan'. Mensen zetten gevolgen op een rijtje en wegen die af. Vaak is daarom in de literatuur gevraagd om gevoelens en emoties beter tot hun recht te laten komen. Emoties zijn eigenlijk heel korte verbindingen tussen een behoefte en een neiging om bepaald gedrag te vertonen, zonder al te veel redenatie. Deze affectieve processen hebben in de sociaal-cognitieve modellen geen plaats maar zouden die wellicht kunnen krijgen. In mijn beeldspraak: hersenpan en hart kunnen goed samenwerken.

Manstead en Parker (1995) onderscheiden affectiveve evaluaties (positieve en negatieve gevoelens van het individu) van de meer cognitieve kosten-baten analyses die b.v. in de theorie van gepland gedrag zijn opgenomen als overwegingen en tonen aan dat deze een aparte plaats in het model van Ajzen verdienen. Ook in bredere zin 
wordt er in de attitude-literatuur wel op gewezen dat attitudes met name op affect of juist vooral op cognities kunnen zijn gebaseerd (b.v. Verplanken, Hofstee en Janssen, 1998; Zanna en Rempel, 1988). Vooral wanneer cognitieve en affectieve factoren niet met elkaar overeenstemmen ontstaat een interessant conflict voor mensen. Daarvoor haal ik een voorbeeld uit onderzoek naar mensen met een grote kans op erfelijk hoog cholesterol (de Vries en Wolfs, in voorbereiding). Wanneer bij én der ouders deze aandoening is geconstateerd is de kans dat een kind erfelijk is belast vijftig procent. Door het cholesterol te laten meten kan men een eerste indicatie voor de aranwezigheid van erfelijke belasting krijgen. Toch ziet een fors aantal van deze kinderen af van de mogelijkheid om zich te laten testen op hun cholesterol. Zij zijn wel overtuigd van het nut van zo'n test, ook van de ernst van de aandoening, vinden zelfs dat ze eigenlijk alle informatie die nuttig is om gezond te blijven zouden moeten verzamelen. Toch doen ze het niet. Degenen die we spraken zijn bang dat ze hun levensstijl drastisch zullen moeten aanpassen wanneer blijkt dat ze inderdaad verhoogd cholesterol hebben, hetgeen overigens grotendeells op een misverstand berust. Maar ze zijn bang om patiënt te worden, met alle consequenties vandien. Ze zijn meer bezig hun negatieve emoties (zoals angst en onzekerheid) te reduceren dan om het mogelijke probleem op te lossen. Gedeeltelijk doen ze dat door rationalisaties (ach, dat is eigenlijk iets voor oudere mensen), gedeeltelijk door duidelijke informatie uit de weg te gaan. Overigens beslissen veel van deze mensen om zich wel te laten testen zodra zij kinderen willen krijgen: de verantwoordelijkheid jegens het nageslacht weegt klaarblijkelijk zwaar. Samen met de Stichting Bloedlink, patièntenorganisatie voor mensen met erfelijke hart-en vaatziekten, gaan wij een project uitvoeren dat gesubsidieerd wordt door ZON. Hierin willen we een duidelijker beeld krijgen van de affectief-cognitieve inconsistentie bij deze doelgroep en op grond daarvan een interventie willen ontwikkelen. Daamaast is in de vakgroep recent expliciet plaats ingenuimd voor onderzoek naar populatiegenetica; vooral IIse Mesters en Jascha de Nooyer zullen hieraan werken. Samen met Anton Dijker zal ik een promotieproject begeleiden dat zich richt op affect en cognitie als gedragsdterminanten. Op dit moment, voor deze rede, is het vooral 
van belang dat ondanks allerlei kennis en cognities, mensen door hun angst worden weerhouden een aanbevolen gedrag uit te voeren: affect domineert in dit geval.

Ook in het verleden heb ik met anderen gewerkit aan affectieve processen (voor een overzicht zie Van der Pligt, Zeelenberg, van Dijk, de Vries en Richard, 1998). Het project van René Richard richtte zich op een speciale vorm van affectieve overwegingen en is in dit kader erg rellevant. Zoals al eerder gesteld is het bij gezondheidsgedrag vaak het geval dat voordelen van het gewenste gezonde gedrag op de lange termijn liggen en de voordelen van het ongewenste, ongezonde gedrag op de kortere termijn. Neem als voorbeeld condoomgebruik: dat wordt ervaren als lastig en onderbrekend tijdens het liefdesspel, en de zorgen over zwangerschap of infectie met een seksueel overdraagbare aandoening komen pas later. De echte effecten komen nog weer later.In dit project hebben we ons vooral beziggehouden met de gevolgen die optreden direct nadat het gedrag is vertoond. Emotionele of affectieve gevolgen waar ik dan aan denk zijn gevoelens als spijt, je zorgen maken, je rot voelen. Sommige mensen houden meer rekening met die gevolgen op de iets langere termijn dan anderen, en het onderzoek toont aan dat juist deze mensen zich ook beter gedragen: mensen met een wat langer tijdsperspectief zeggen vaker een condoom te gebruiken bij seks met een losse of nieuwe partner dan zij die vooral letten op de korte termijn. Hetzelfde is aangetoond voor bijvoorbeeld het eten van 'fast food' en het drinken van teveel alcohol; in het onderzoek van Van Harreveld dat ik zojuist behandelde wordt ook gevonden dat rokers vooral letten op korte termijn effecten. Voor deGVO is het belangrijk dat dit mogelijkheden biedt tot beinvloeding: als men er in slaagt iedereen een langer tijdsperspectief te laten hanteren, zou het condoomgebruik moeten toenemen. Richard, Van der Pligt en De Vries (1996) maakten daarom twee versies van een vragenlijst. In de eerste versie werd studenten gevraagd naar hun oordelen over condoomgebruik. In de tweede, experimentele versie werd andere studenten gevraagd na te denken over hoe zij zich naderhand zouden voelen als ze geen condoom hadden gebruikt bij seks met een nieuwe of losse partner. De studenten in deze tweede groep (en met name de mannelijke) rapporteren een meer positieve 
intentie om condooms te gebruiken dan de studenten uit de eerste groep. Belangrijker is echter de volgende stap. Vijf maanden later kregen dezelfde studenten nogmaals een vragenlijst waarin zij konden aangeven of zij in de tussentijd seks hadden gehad met een nieuwe of losse partner, en of zij daarbij een condoom hadden gebruikt. Het condoomgebruik in de groep die was bevraagd over hun affectieve reacties achteraf was hoger dan bij de anderen. Let wel: dit effect in gedrag is bereikt door in een vragenlijst mensen in plaats van over condoomgebruik zelf na te laten denken over de gevoelens achteraf. Volgens onze interpretatie zijn deze mensen door de vragenlijst gedwongen ook de gevolgen op de iets langere termijn in ogenschouw te nemen. Alleen een andere focus in een paar vragen is dus al voldoende om gedrag te beïnvloeden. Klaarblijkelijk heeft het nadenken over gevolgen op de iets langere termijn dus grote consequenties; dat kan men in interventies stimuleren. Dat is in Maastricht onder anderen toegepast door Herman Schaalma, op het gebied van condoomgebruikbij jongeren (Schaalma en Kok, 2000). Affectieve reacties die men verwacht na bepaald gedrag bepalen dus voor sommige mensen hun gedrag. De mensen die deze langere termijn consequenties niet meewegen kunnen daar eenvoudig toe worden aangezet, met gevolgen voor hun gedrag.

Het bovenstaande gaat nog steeds over cognitieve processen; over afwegen en oordelen. Kortom, het gaat over processen "in de hersenpan" vooral in combinatie met emotionele of affectieve processen, "het hart". Ik heb echter in het voorgaande al gesuggereerd dat dergelijke afwegingen soms wellicht helemaal niet plaatsvinden maar dat mensen in tal van situaties reageren op basis van een gevoel, intultie of automatisme, dus op hun "ruggengraat". Daar zal ik nu eerst proberen wat meer evidentie voor aan te dragen.

\section{Automatische processen}

Strikt genomen suggereren waardeverwachtingsmodellen dat mensen iedere keer dat zij iets doen een afweging maken. Dat kan natuurlijk niet, zelfs niet in de beperkte vorm op grond van een klein aantal individueel saillante overwegingen of affectieve reacties. We zouden 
nergens meer aan toekomen, gewoon omdat dat teveel tijd en moeite kost. Een wat zachtere vorm zou zijn dat die afwegingen niet nodig zijn omdat ze al eerder hebben plaatsgevonden, en mensen het resultaat van een eenmaal gemaakte afweging onthouden en weer uit hun geheugen kunnen opdiepen. Dit idee ligt ten grondslag aan verschillende modellen, zoals dat van Fazio (1990).

Fazilo stelt dat attitudes alleen door beredeneerde afweging tot stand komen indien mensen voldoende gemotiveerd zijn om tot een juist oordeel te komen en wanneer ze daartoe ook in de gelegenheid zijn (dus bijvoorbeeld niet te veel andere dingen aan hun hoofd hebben of afgeleid worden). Wanneer motivatie of gelegenheid ontbreken worden de gecontroleerde processen vervangen door meer automatische: een opgeslagen evaluatie of attitude wordt opgehaald. uit het geheugen. Dat gebeurt met name wanneer dit een zogenaamde sterke attitude is: wanneer er een heel sterke link ligt tussen de stimulus (een object of situatie) en de attitude, is de aanwezigheid van de stimulus genoeg om een evaluatieve respons te activeren. Het ene proces is dus intentioneel en opzettelijk; het andere spontaan. Volgens Fazio bestaan er ook mengvormen, maar daar ga ik hier verder niet op in: er is dus een continuum van automatisch, $d . w . z$. onintentioneel en spontaan, zonder moeite, ongecontroleerd en onbewust, naar gecontroleerd: intentioneel, energievretend, gecontroleerd en bewust (zie Bargh, 1994). Hetzelfde continuüm wordt door vele andere auteurs gesuggereerd, bijvoorbeeld aangaande attitudeverandering, persoonswaarneming, stereotypering en beslissen. Op dit moment zijn de zogenaamde "dual process" theorieën dan ook erg in zwang in de cognitieve sociale psychologie (Chaiken en Trope, 1999).

Lange tijd is gedacht dat het gebruik van automatische associaties niet is te onderdrukken of af te leren. Zo werd bijvoorbeeld aangenomen dat stereotiepe denkbeelden over andere groepen spontaan bij mensen opkomen, en dat men alleen de uiting van die stereotypen zou kunnen onderdrukken. Zoals gezegd worden automatische associaties gevormd door herhaaldelike paring van reacties aan stimuli. Dat feit heeft voor Kawakami, Dovido, Moll, Hermsen, en Russin (2000) het uitgangspunt gevormd om na te denken over het afleren van die associaties. Met andere woorden: zij proberen mensen te leren de 
automatische activatie van stereotypen (met de evaluatieve en gedragstendensen die daarbij horen) te laten onderdrukken en te vervangen door een andere associatie. In hun onderzoek blijkt dat het herhaaldelijk bewust onderdrukken van een stereotype aangaande een groep (door op stereotype kenmerken bewust te antwoorden dat die niet van toepassing zijn) er toe leidt dat men minder geneigd is die stereotypen uberhaupt te gebruiken. Meer in het algemeen impliceert dit dat de (onbewuste) associatie van een bepaalde stimulus of stimulussituatie aan een bepaalde respons kan worden verbroken. $\mathrm{Nu}$ vereist dit nogal wat training en moet je de personen in kwestie individueel benaderen. Desalniettemin acht ik deze ontwikkeling van groot belang, juist omdat lange tijd gedacht is dat het onmogelijk is de activatie van stereotypen te onderdrukken (maar alleen de uiting daarvan).

In feite is dit een voorbeeld van wat men zou kunnen noemen 'ontautomatiseren". Een andere vorm kan worden afgeleid uit het eerder geschetste continuum van automatisch naar gecontroleerd. Gegeven voldoende tijd, energie en motivatie kunnen mensen zich weer bewust worden van reacties die zich anders automatisch afspelen. In feite gebeurt dit al in de GVO, en ook in Maastricht. Alle interventies die zich richten op verhoging van de waargenomen controle zou men kunnen opvatten als pogingen om te ont-automatiseren: men poogt het verband tussen moeilijke situaties en ongewenst gedrag te verminderen en te vervangen door een gecontroleerd of een ander gedrag (zie b.v. het werk van de groep rond Hein de Vries). Gedragswijzen kunnen net als attitudes zijn opgeslagen in het geheugen en vervolgens in een passende situatie simpel worden geactiveerd en uitgevoerd. Het duidelijkste voorbeeld betreft gewoonten. Een gewoonte is niets anders dan een gedragsrespons die automatisch wordt geactiveerd in een bepaalde situatie of bij een bepaald doel. Men gaat niet gemakkelijker door een beslissingsproces, maar de hele afweging is zelfs afwezig (zie bijvoorbeeld Aarts, Verplanken en van Knippenberg, 1998). Als u bijvoorbeeld gewend bent iedere dag, 's middags na het werk bij thuiskomst, eerst eens een kop thee te drinken en dan het eten te bereiden met een glaasje jenever erbij, dan doet $\mathbf{u}$ dat gedachtenloos. Dat is het kenmerk van sterke 
gewoonten: men volgt ze automatisch. Om de routine te doorbreken heeft $u$ een aanleiding nodig, en dat kost ook energie.

Voor de gezondheidsvoorlichting is dit uiterst relevant: veel gedrag met implicaties voor de gezondheid wordt zo vaak uitgevoerd dat er ingesleten gewoontes ontstaan. Dat vereist wellicht een andere beinvloedingsstrategie dan overtuigen alleen: immers men kan niet ingrijpen in een afweging die niet gemaakt wordt.

In het kader van het afleren van gewoontes en het aanleren van nieuwe is het interessant even stil te staan bij het werk van Gollwitzer (1996; 2000) over "goal achievement", het bereiken van doelen. Vaak hebben mensen wel de intentie om bepaald gedrag te veranderen, maar Gollwitzer benadrukt dat zij ook vaak niet goed weten hoe dat dan moet. Volgens hem is het van belang niet alleen een doel te hebben maar ook voorbereid te zijn op de manier om dat doel te bereiken. Dit noemt hij ímplementatie intenties: plannen over gewenst gedrag in de vorm: "als situatie X zich voordoet, dan reageer ik zo". De persoon denkt na over de situaties waarin het gewenste gedrag vertoond kan worden, en simuleert mentaal hoe dat zou kunnen. Daarmee worden zowel die situatie als het effectieve gedrag meer toegankelijk: zodra de persoon in de situatie belandt wordt die beter als zodanig herkend en het gewenste gedrag min of meer automatisch vertoond. Of, zoals Gollwitzer dat stelt, de controle over het gedrag wordt overgeheveld naar de omgeving. Leuke studies op het gebied van de gezondheidsbevordering komen uit Engeland. Sheeran en Orbell (1999) gaven mensen die zeiden dat ze van plan waren iedlere dag een vitaminepil te slikken een potje mee naar huis. Alleen de helft van deze mensen vroegen ze om eerst aan te geven hoe en wanneer ze die dagelijkse pil gingen slikken. Deze mensen sloegen minder pillen over dan degenen die alleen hadden verklaard van plan te zijn iedlere dag een pil te nemen. Orbell, Hodgkins en Sheeran (1997) vroegen vrouwen in hoeverre ze van plan waren borst zelf-onderzoek te doen. Bovendien lieten ze de helft van deelneemsters in hun onderzoek nadenken over hoe en wanneer ze dit in de komende maand zouden gaan doen. Van de vrouwen die een ferme intentie hadden deed $53 \%$ dat ook inderdaad; van de vrouwen met een ferme intentie en die ook hadden nagedacht over de implementatic intentie verrichtte $100 \%$ 
daadwerkelijk borst zelf-onderzoek. Dezelfde groep verzamelde verdere positieve evidentie aangaande revalidatie en sport; Verplanken en Faes (1999) aangaande de consumptie van groente en fruit. Aarts, Dijksterhuis en Midden (1999) tonen aan dat inderdaad zoals verondersteld de relevante situaties (of liever: woorden die daaraan refereren) sneller worden herkend wanneer er implementatie intenties zijn gevormd. Zelf heb ik in samenwerking met mijn Britse collega's Abrahams en Sheeran een studie naar condoomgebruik. Op dit moment analyseren we de gegevens, maar zijn hoopvol dat het doordenken van de manier waarop condoomgebruik kan worden aangekaart en uitgevoerd positieve effecten heeft. Ook in onderzoek van de capaciteitsgroep GVO hebben de implementatie intenties inmiddels een plaats gekregen.

Het lijkt er dus sterk op dat een positieve intentie om gezond gedrag te vertonen vaak niet genoeg is; mensen moeten daarenboven zich voorstellen hoe ze dat gedrag zullen inpassen in hun eigen situatie. Het gedrag dat mensen vertonen staat relatief los van hun intentie om te veranderen, maar wordt gedomineerd door kenmerken van de situatie die min of meer automatisch tot een bepaalde reactie leiden. Het vormen van implementatie intenties bereidt mensen voor op het vertonen van nieuw gedrag in die situatie. Daartoe wordt de handeling gesimuleerd en niet alleen het doel; daarmee gaat het nieuwe gedrag qua inbedding in het cognitief systeem lijken op een gewoonte (zie ook Aarts en Dijksterhuis, 2000). En omgekeerd: implementatie intenties stellen de persoon in staat om ongewenste gedragingen, ideeën en gevoelens niet meer te vertonen.

Een andere manier om ingesleten gewoontes te veranderen is het aanpassen van de situationele cues. Als automatismen korte associatieve verbanden tussen bepaalde stimuli en reacties zijn kan men ook proberen de stimuli te verwijderen. In de preventie is dit al toegepast door bijvoorbeeld tabaksreclame te verbieden. Een andere vorm betreft de aanpassing van de inrichting van café's. Jongeren geven in kroegen rondjes, en het gebruik is dat iedere tafelgenoot een rondje moet geven. Wanneer de tafels groot zijn leidt dat tot overmatig drankgebruik. Wat is er gemakkelijker dan het verkleinen van de tafels? 
Intentie en gedrag

De ideečn over implementatie intenties veronderstellen dat er sprake is van een positieve doel-intentie: het helpt om je geestelijk voor te bereiden wanneer je vast van plan bent iets te bereiken. De volgende vraag is dan: hoeveel intentionele gedragingen vertonen mensen? Recente theorievorming laat zien dat de capaciteit om je bewust ergens toe te zetten heel beperkt is. Baumeister en zijn collega's (bv. Baumeister, Bratslavsky, Muraven en Tice, 1998) hebben gedemonstreerd dat het bewust negeren van de aandrang om iets te doen zoveel (cognitieve) energie kost dat controle over een volgend gedrag onwaarschijnlijk wordt. Zij geven dit weer in hun theorie over "ego-depletion", uitputting van het zelf. In één van hun onderzoeken zetten zij deelnemers aan een tafel waarop heerlijke chocoladekoekjes staan, maar ook radijsjes. Een deel van de proefpersonen wordt gevraagd van de koekjes af te blijven, maar wel radijsjes te eten. Het blijkt dat deze mensen in een vervolgtaak waarin ze onmogelijke puzzeltjes moeten oplossen, minder lang volhouden dan anderen. Het gaat niet om de precieze taken die in dit onderzoek gebruikt worden, maar om het feit dat controle over het eigen gedrag klaarblijkelijk zoveel moeite kost dat men dat niet al te frekwent kan doen.

Baumeister schat dat zo ongeveer vijf procent van alle gedrag bewust wordt aangestuurd, en niet meer.

Soms leiden situationele prikkels dan ook tot gedrag zonder dat er uberhaupt sprake is van bewuste controle, dus van intenties. Dat noem ik vandaag "ruggengraat", naar analogie van de reflexen. Iemand die dreigt zich aan een hete pan te branden trekt de hand onmiddellijk terug. Die reflex wordt niet aangestuurd door de hersenen, maar in een korter circuit via de ruggengraat. Een automobilist die een hond ziet oversteken trapt op de rem, zonder dat daar een intentie of beslissing aan vooraf is gegaan: de waarneming van de hond is genoeg om de actie te veroorzaken. Mijn beeldspraak gaat hier in zoverre mank, dat er natuurlijk best hersenactiviteit plaatsvindt om dit aan te sturen, maar er is geen bewuste gedachtenstroom die de handeling bepaalt. Er moet wel op enig moment in het verleden een relatie tussen de prikkel 
(de overstekende hond) en de reactie (remmen) zijn gelegd. Dat kan via simpele leerprincipes zoals conditionering en het vaak vertonen van gedrag als reactie op een bepaalde stimulus. Zo worden gedragingen automatische reacties op een situatie: we ontwijken obstakels, drinken koffie of juist thee bij het ontbijt, nemen vier boterhammen mee naar het werk, en dat allemaal zonder er bij na te denken.

Voor de persoon zelf komt dat overigens vaak over alsof er wel degelijk een beslissing is genomen. Veroorzaakt men door het ontwijken van een overstekende hond een ongeluk, dan is het excuus: "Ik wilde de hond ontwijken". Dus: alhoewel er geen intentie aan het gedrag te pas komt spreken wij over onszelf alsof we volledige controle hebben over ons denken en gedrag (zie ook Wegner en Wheatley, 1999).

Wat betekent dit nu allemaal? Volgens mij (en velen met mij) zijn er tal van gedragingen, en dus ook gezondheidsgedragingen, die worden veroorzaakt door simpele stimuli in de omgeving. Mensen nemen die waar, en met de waarneming wordt ook een idee, emotie, doell, motivatie of gedrag geactiveerd. Zonder controle en gedachtenloos reageert men. Drie voorbeelden uit de wereld van de gezondheid wil ik hier behandelen, de eerste over motivatie.

In de Financial Times van 13 oktober 2000 stond een interessant artikel over anti-rookcampagnes. Iemand die aan die campagnes meewerkt vertelt daarin over de manier waarop de tabaksindustrie aansluit bij onbewuste processen. Volgens deze meneer roken jongeren om te rebelleren tegen hun ouders. Honderd procent van de jongeren weet hoe slecht roken is, maar het nemen van risico past bij het (waarschijnlijk onbewuste) motief om tegen je ouders in opstand te komen. De tabaksindustrie heeft (nog steeds volgens de zegsman) daarop ingespeeld door sigarettenverpakkingen in de kleuren van dood en gevaar uit te voeren (voornamelijk zwart en rood). Eén fabriek ging zelfs zover een merk te introduceren dat "Death" heet. In de context van wat ik net beschreef sluiten de kleuren en de merknaam aan bij motivaties die leven bij de jongeren; door gebruik te maken van die onbewuste associaties wordt het produkt aantrekkelijker.

Een tweede voorbeeld betreft het anti-rookprogramma van Allen Carr. In deze, naar het schijnt uiterst succesvolle, interventie wordt er 
rekening mee gehouden dat stoppen met roken een kleine kans van slagen heeft als dat gebeurt op basis van wilskracht. Dat sluit direct aan bij de theorie over 'ego-depletion'. Deelnemers analyseren situaties waarin zij gewend zijn te roken. In deze methode probeert men vervolgens de link tussen die situaties en het gedrag te verbreken en er een alternatief voor in de plaats te stellen. Bijvoorbeeld: na een spannende vergadering hoefje niet meer te roken, het is gewoon niet meer nodig: je kunt ook andere reacties vertonen. Overigens wordt dit wel aangevuld met andere vormen van beïnvloeding, zoals informeren over kosten en ongezondheid van nicotinegebruik. Ook wordt geprobeerd de lange termijn consequenties duidelijk te maken door te zeggen: "Geef mij maar twintigduizend gulden, dan krijg jij iedere dag een pakje sigaretten". Niemand wil dat, omdat dan ineens de kosten heel duidelijk worden. Het commercieel succes van de methode blijkt uit het feit dat er nu ook cursussen worden aangeboden ter bestrijding van vliegangst, alcoholmisbruik, en gewichtsverlies. Als voorbeeld van de manier waarop onbewuste processen kunnen worden onderzocht maak ik nu een overgang naar het automatisch belnvloeden van dergelijke affectieve reacties.

\section{Automaticiteit en affect}

Om aan te tonen dat affect op onbewuste manier oordelen kan beïnvloeden hebben Murphy en Zajonc (1993) een interessant experiment gedaan. Zij lieten mensen oordelen geven over stimuli die geen enkele betekenis voor hen hadden, zoals Chinese karakters en Turkse woordjes. Die stimuli werden voorafgegaan door heel korte vertoning van blijde of treurige gezichtjes, zoals dat heet onder de waarnemingsdrempel. De deelnemers in het onderzoek konden deze dus niet bewust waarnemen, al registreerden hun ogen de gezichtjes wel. De evaluatie van de betekenisloze stimuli bleek beînvloed te worden door de positieve en negatieve uitdrukking op die kort vertoonde gezichten. Deze invloed is onbewust, en zonder dat er een redenering aan ten grondslag kán liggen, want die gezichtjes worden niet eens gezien. Dat onbewuste is zelfs essentieel: wanneer de 
gezichtjes die aan de Chinese karakters voorafgaan bewust worden waargenomen, verdwijnt het effect. Klaarblijkelijk nemen meer gecontroleerde processen dan de plaats in van de automatische. $\mathrm{Nu}$ weten we uit allerlei onderzoek dat dergelijke op affectieve reacties gebaseerde evaluaties gevolgen hebben: ze bepalen waar de aandacht vervolgens naar uitgaat en ze hebben invloed op andere oordelen die gemaakt worden. Dat was de basis voor het onderzoek dat Kirsten Ruijs op dit moment uitvoert aan de Universiteit van Amsterdam en dat is gesubsidieerd door NWO. In haar onderzoek gaat het niet meer over de evaluatie van betekenisloze stimuli, maar staan de oordelen over andere personen centraal. Het idee is dat je eerste, automatische oordelen over personen, consequenties hebben voor de verdere verwerking van informatie over die personen.

Inmiddels heb ik bericht ontvangen over een andere subsidie-aanvraag bij NWO waaraan een soortgelijk idee ten grondslag ligt, maar waarin we ons hier in Maastricht zullen richten op allerlei voedingsproducten zoals genetisch gemanipuleerd voedsel. Opnieuw is het idee dat initièle oordelen die op onbewuste manier tot stand komen gevolgen hebben voor verdere attitudevorming en informatieverwerking.

\section{Slot}

In deze lezing heb ik geprobeerd aan te geven dat er naast de "hersenpan"theorieën over bewuste afwegingen behoefte bestaat aan modellen die affectieve processen in kaart brengen en kennis over automatische processen. Net als bij het menselijk lichaam leert ook deze anatomische les dat hersenpan, hart en ruggengraat samenwerken. GVO is gebaat bij theorievorming op alledrie de gebieden. In interventies kunnen we beter aansluiten bij determinanten van gedrag wanneer we de verschillende processen die zich in het organisme afspelen leren begrijpen. Een flink deel van de ideeên die $i k$ heb aangedragen heeft al een plaats gevonden in het onderzoeksprogramma van de leden van de capgroep GVO. Sommige andere hoop ik samen met anderen uit te werken. Dat is een belangrijk doel in de komende jaren. 
Er zijn nog meer doelen. GVO was vroeger een vak dat zich alleen richtte op de effecten van informatie, maar langzaam is dat zich aan het verbreden. Ik wil meer te weten komen over de implementatie van innovaties, over de zogenaamde 'community-approaches' waarin mensen vanuit een sociaal systeem worden benaderd, enzovoort. Maar dat kan ik niet allemaal in drie kwartier behandelen. Ik beloof u: $u$ hoort nog van mij.

Mijnheer de Rector,

Dames en heren,

Natuurlijk wijk ik niet af van de gewoonte om aan het eind van mijn rede mijn dank te uiten. Ik dank de Universiteit Maastricht en de Faculteit der Gezondheidswetenschappen voor het in mij gestelde vertrouwen. $\mathrm{Nu}$ is het mij aan de ene kant gemakkelijk gemaakt: ik schat zo in dat de capaciteitsgroep Gezondheidsvoorlichting éen van de meest produktieve groepen is in de faculteit en wellicht ook binnen de universiteit. Ik zal proberen $\mathrm{u}$ daar aan te herinneren, op allerlei manieren.

Die mooie erfenis heb ik voor een belangrijk deel te danken aan mijn voorganger, Gerjo Kok. Gerjo, ik ken je al sinds 1976 , was je paranimf en eens je medewerker; nu is het mijn taak jou te doen vergeten. Dat zal moeilijk worden, maar ik hoop dat je me daarbij wilt helpen met raad en daad.

Beste collega's in de vakgroep Gezondheidsvoorlichting, jullie zijn voor het overige verantwoordelijk voor de gunstige situatie waarin ik ben begonnen. Ik meen het oprecht wanneer ik zeg dat ik bewondering heb voor wat jullie de afgelopen jaren hebben opgebouwd. Ik hoop dat $\mathrm{ik}$ jullie kan helpen dat succes verder uit te bouwen.

Ook een woord van dank voor mijn oud-collega's, zonder uitzondering. Jullie zijn met te veel om allemaal te noemen. Maar speciaal wil ik toch danken Joop van der Pligt, met wie ik in de afgelopen jaren een vruchtbare werkrelatie maar ook een mooie vriendschap heb gesmeed. Beste Joop, ik hoop dat we dat ondanks de afstand voort kunnen zetten.

En over afstand gesproken: éen van de mensen die de meeste last heeft van mijn vertrek naar Maastricht is mijn dochter Jorien. Ik ben heel 
blij dat je er vandaag ook bij bent en hoop dat ik je niet al te veel heb verveeld.

Ook wil ik mijn dank uiten naar mijn ouders. Syb en Trees, jullie hebben me ooit een automatische motivatie meegegeven om er wat van te maken: die zal ik de komende tijd hard nodig hebben.

Veel dank en daarnaast nog veel meer gaat uit naar Carolien. Carolien, zonder jou zou ik niet weten waar ik moest blijven. Gelukkig weet ik dat nu wel.

Ten slotte wil ik u allemaal, die de moeite heeft genomen om hier vandaag aanwezig te zijn, bedanken. Het is voor mij een grote eer dat $\mathrm{u}$ in zo grote getale naar mij heeft willen luisteren.

Ik heb gezegd. 



\section{Referenties}

Aarts, H., \& Dijksterhuis, A. (2000). Habits as knowledge structures: Goal directed automaticity in habitual actions. Joumal of Personality and Social Psychology, 78, 53-63.

Aarts, H., Dijksterhuis, A., \& Middlen, C. (1999). To plan or not to plan? Goal achievement of interruptingm the performance of mundane behaviors. European Joumal of Sacial Psychology, 29, 971-980.

Aarts, H., Verplanken, B., \& van Knippenberg, A. (1998). Predicting behavior from actions in the past: Repeated decision making or a matter of habit? Journal of Applied Social Psychology, 28, 1355-1374.

Ajzen, I (1991). The theory of planned behavior. Organizational Behowior and human Decision Processes, 50, 179-211.

Bargh, J.A. (1994). The Four Horsemen of automaticity: Awareness, efficiency, intention and controll in social cognition. In R.S. Wyer, JR., \& T.K. Srull (Eds.). Handbook of social cognition (2nd ed., 1-40). Hillsdale, NJ: Erlbaum.

Baumeister, R.F., Bratslavsky, E., Muraven, M., \& Tice,D.M. (1998). Egodepletion: Is the active self a limited resource? Journal of Personality and Social Psychology, 74, 1251-1265.

Chaiken, S., \& Trope, Y. (Eds.) (1999). Dual process theories in social psychology. New York, Guilford.

Fazio, R.H. (1990). Multiple processes by which attitudes guide behavior: The MODE model as an integrative framework. In M.P. Zanna (Ed.), Advances in experimental social psychology (Vol. 23, pp. 75-109). San Diego, Cal.: Academic Press.

Gollwitzer, P.M. (1996). The volitional benefits of planning. In P.M. Gollwitzer \& J.A. Bargh (Eds.), The psychology of action: Linking cognition and mativation to behavior (287-312). New York: Guilford.

Gollwitzer, P.M. (1999). Implementation intentions. Strong efects of simple plans. American Psychologist, 54, 493-503.

Jaccard, J., Radecki,C., Wilson, T., \& Dittus, P. (1995). Methods for identifying consequential beliefs: Implications for understanding attitude strength. In.

R.E. Petty \& J.A. Krosnick (Eds.) Attirude sirength: contecedents and consequences (337-359). Mahwah, NJ: Erlbaum.

Kawakami, $\mathrm{K}$, et al (2000), Just say no (to stereotyping): effects of training in the negation of stereotypic associations on stereotype activation. Journal of Personality and Social Psychology, 78, no.5, 871-888

Manstead, A.S.R. \& Parker, D. (1995). Evaluating and exctending the theory of planned behaviour. In W. Stroebe \& M. Hewstone (eds.) European Review of Social Psychology (voll 6, 69-95). Chichester: Willey

Murphy, S. T., \& Zajonc, R.B. (1993). Affect, cognition and awareness:

Affective priming with suboptimal and optimal stimulus presentation. Joumal of Personality and Sacial Psychology, 64, 723-739. 
Orbell, S., Hodgkinss, S. \& Sheeran, P. (1997). Implementation intentions and the theory of planned behavior. Personality and Social Psychology Bulletin, $23,945-954$.

Richard, R, van der Pligt, J \& de Vries, N.K. (1996b). Anticipated regret and time perspective: Changing sexual risk-taking behavior. Joumal of Behawioral Decision Making, 9, 185-99

Schaalma, H. \& Kok, G. (2000). A school aids prevention program in the Netherlands. In: K. Bartholomew, G.Parcel, G.Kok \& N.Gottlieb (in druk) Intervention mapping: a process for designing theory-and evidence based health education and promotion programs. Mountain View, CA: Mayfield.

Sheeran, P., \& Orbell, S. (1999). Implementation intentions and repeated behaviors: Augmenting the predictive validity of the theory of planned behavior. European Joumal of Social Psychology, 29, 349-370.

Taylor, S.E. (1998). The social being in social psychology. In D.T. Gilbert, S.F.Fiske \& G. Lindzey (eds.). Handbook of social psychology (4th ed., 5895). Boston, MA: McGraw-Hill.

Van der Pligt, J., de Vries N.K. Manstead, A \& van Harreveld, F. (2000). The importance of being selective: weighing the role of attribute importance in attitudinal judgement. In: Advances in Experimental Social Psychology, vol. $32,135-200$.

Van der Pligt, J., Zeelenberg, M., van Dijk, W.W., de Vries, N.K. \& Richard, R. (2000). Affect, attitudes and decisions: let"s be more specific. In: W. Stroebe \& M. Hewstone (eds.) European Review of Social Psychollogy (vol. 8, 33-66). Chichester: Wiley.

Verplanken, B., \& Faes, S. (1999). Good intentions, bad habits and effects of forming implementation intentions on healthy eating. European Joumal of Social Psychology, 29, 591-604.

Verplanken, B., Hofstee, G. \& Janssen, H.J.W. (1998). Accessibility of affective versus cognitive components of attitudes. European Journal of Social Psychology, 28, 23-35.

Vries, N.K. de, \& Wolfs, J. (in voorbereiding). De rol van affect en cognitie bij de besissing om diagnostische informatie te verkrijgen.

Vries, H.de \& Brug, J. (1999). Computer-tailored interventions motivating people to adopt health promoting behaviours: Introduction to a new apporach. Patient Education and Counseling, 36, 99-105

Wegner, D.M., \& Wheatley, T. (1999). Apparent mental causation. Sources of the experience of free will. American Psychologist, 54, 480-492.

Zanna, M.P. \& Rempel, J.K. (1988). Attitudes: a new look at an old concept. In:

D. Bar-Tall \& A. Kruglanski (eds.) The social psychology of knowledge,

(315-334). New York: Cambridge University Press 